\title{
Analisis Kandungan Formalin Dan Boraks Pada Ikan Asin Dan Tahu Dari Pasar Pinasungkulan Manado Dan Pasar Beriman Tomohon
}

\author{
Hasna Ma'rufa*, Meiske S. Sangia, Audy D.Wuntua \\ aJurusan Kimia, FMIPA, Unsrat, Manado
}

KATA KUNCI ABSTRAK

Ikan Asin, Tahu, Formalin,

Boraks

KE Y W OR D S

Salted Fish, Tofu,

Formaldehyde, Borax
Ikan asin dan tahu merupakan sumber protein yang banyak dikonsumsi
masyarakat Indonesia, mudah diperoleh, dan harganya murah. Bahan
pangan ini, cepat mengalami proses pembusukan yang disebabkan oleh
pertumbuhan mikroorganisme, oleh sebab itu produsen ikan asin dan
tahu sering menggunakan bahan pengawet agar produk ini tidak cepat
rusak, terutama bahan pengawet yang tidak diizinkan. Penelitian ini
bertujuan untuk menguji secara kualitatif keberadan formalin dan boraks
pada ikan asin dan tahu serta menentukan secara kuantitatif jika produk
pangan tersebut positif mengandung formalin dan boraks. Sampel yang
digunakan dalam penelitian ini adalah ikan asin dan tahu yang diperoleh
dari pasar Pinasungkulan Manado dan pasar Beriman Tomohon. Untuk
analisis kualitatif formalin digunakan kit pengujian dan pereaksi Schiff
sedangkan untuk analisis secara kuantitatif formalin digunakan
spektrofotometer UV-Vis. Untuk analisis kualitatif boraks digunakan kertas
tumerik. Hasil penelitian menunjukkan bahwa ikan asin yang dijual di
pasar Pinasungkulan Manado dan Pasar Berimam Tomohon tidak
mengandung boraks tetapi positif mengandung formalin dengan kadar
rata-rata 0,099-0,289 ppm sedangkan tahu yang dijual di pasar
Pinasungkulan Manado dan pasar Berimam Tomohon tidak terdeteksi
mengandung formalin dan boraks
A B S T R A T

Salted fish and tofu are sources of proteinconsumed by most people in Indonesia for their price and availability. These products, however, are easily deteriorated by microorganism activity and the producers tend to use preservatives to avoid the product degradation. In fact, some producers use chemicals which are prohibited for preservation because of their effects on human health. This research was aimed to qualitatively test the presence of formaldehyde and borax and to quantitatively examine the concentration of these chemicals in salted fish and tofu when the qualitative test showed positive result. Samples used in this research were salted fish and tofu obtained from traditional markets Pinasungkulan Manado and BerimanTomohon. Test kit and Schiff solution were used in qualitative test and spectrophotometer UV-Vis was used in quantitativetest of formaldehyde. Tumeric paper, on the other hand, was used qualitative analysis of borax. The results showed that salted fish obtained from Pinasungkulan Manado and Beriman Tomohondid not contain borax, but containedformaldehyde at the level of 0,099-0,289 ppm. On the other hand, tofu obtained from the traditional markets did not find to contain

TERSEDIA ONLINE

01 Agustus 2017

*Corresponding author: Jurusan Kimia FMIPA UNSRAT, Jl. Kampus Unsrat, Manado, Indonesia 95115; Email address: maarufhasna@gmail.com 


\section{Pendahuluan}

Kesehatan merupakan hal paling utama yang sangat diperlukan dalam diri setiap orang, karena seluruh aktivitas yang akan kita lakukan tidak akan berjalan dengan lancar apabila kesehatan kita terganggu. Kesehatan berhubungan dengan bahan pangan. Bahan pangan yang dikonsumsi sangat mempengaruhi tingkat kecerdasan dan kesehatan seseorang.

Rinto dan Arafah (2009) menerangkan bahwa secara fisik pangan yang aman adalah bahan pangan yang bersih dari bahan-bahan yang tidak dapat dicerna oleh tubuh yaitu plastik, logam dan bahan bahan-bahan lainnya yang mengganggu pencernaan manusia, secara kimiawi dapat berasal dari zat-zat berbahaya yang tidak boleh digunakan dalam bahan pangan seperti formalin, boraks, insektisida serta bahan tambahan makanan yang sangat dibatasi penggunaannya. Penggunaan zatzat kimia berbahaya pada bahan pangan seperti formalin, boraks dan insektisida serta bahan tambahan makanan lainnya sangat dibatasi penggunaannya. Penggunaan bahan tambahan pada makanan belakangan ini membuat makanan tampak lebih menarik, tahan lama, serta rasa dan teksturnya lebih sempurna. Pemakaian bahan pengawet sepatutnya diatur dan diawasi sebab dalam kadar tertentu akan menimbulkan masalah kesehatan bagi konsumen (Sinaga, 2009).

Formalin merupakan bahan kimia yang digunakan sebagai pengawet mayat dan hewan penelitian serta di pakai sebagai zat antiseptik untuk membunuh virus, bakteri, dan jamur (Sari et al., 2014). Pada konsentrasi <1\%, formalin digunakan sebagai pengawet untuk berbagai bahan non pangan seperti cairan pencuci piring, pelembut, shampo mobil, lilin dan karpet. Formalin dapat bereaksi cepat dengan lapisan lendir saluran pencernaan dan saluran pernafasan, di dalam tubuh cepat teroksidasi membentuk asam format terutama di hati dan sel darah merah. Pemakaian formalin pada makanan dapat mengakibatkan keracunan yaitu rasa sakit perut yang akut disertai muntah-muntah dan timbulnya depresi susunan syaraf (Suparwiono dan Hudaidah. 2014). Boraks umumnya digunakan untuk mengawetkan kayu dan penghambat pergerakan kecoa (Bambang, 2008). Mengkonsumsi makanan yang mengandung boraks memang tidak secara langsung berakibat buruk, tetapi boraks akan menumpuk sedikit demi sedikit karena diserap dalam tubuh. Seringnya mengonsumsi makanan yang mengandung boraks akan menyebabkan gangguan otak, hati, dan ginjal (Triastuti et al., 2013).

Produk pangan pada umumnya yang menggunakan formalin dan boraks adalah bahan pangan segar atau makanan olahan yang mengandung kadar air tinggi, yang tidak dapat disimpan dalam jangka waktu yang lama, terutama jika disimpan pada suhu ruang. Produk pangan yang sering diawetkan dengan formalin antara lain ikan segar ,tahu, tempe, mie basah mentah/mie segar
(Puspasari dan hadijanto., 2014). Produk pangan lainnya yang juga sering diawetkan adalah ikan asin, pengasinan ikan adalah salah satu cara pengawetan ikan agar tidak mengalami kebusukan oleh bakteri pembusuk dengan menambahkan garam 15-20\% pada ikan segar. Penambahan formalin pada ikan dengan tujuan untuk meningkatkan nilai jual dan kualitas dari ikan asin, terutama menambah masa simpan (Mirna et al., 2016).

Tahu dan ikan merupakan bahan makanan yang mudah mengalami kerusakan terutama kerusakan yang disebabkan oleh pertumbuhan mikroorganisme, seperti bakteri, kapang dan khamir. Penambahan formalin dan boraks memang secara efektif dapat menghambat pertumbuhan mikroorganisme, oleh karena itu pada penelitian ini akan dilakukan analisis kandungan formalin dan boraks pada ikan asin dan tahu yang di jual dipasar Pinasungkulan Manado dan pasar Beriman Tomohon.

\section{Material dan Metode Alat dan Bahan}

Alat utama yang digunakan adalah peralatan destilasi dan spektrofotometer UV-Vis Simadzu. Analisis kimia dilakukan dengan menggunakan tes kit formalin dan pereaksi Schiff

\section{Preparasi Sampel}

Sampel yang digunakan adalah ikan asinyang dibuat dari ikan kakatua (Scarus sp.) yang diperoleh dari pasar Pinasungkulan Manado dan pasar Beriman Tomohon. Untuk sampel tahu di peroleh dari pabrik yang ada dikota Manado dan Tomohon serta tahu yang ada dipasar Pinasungkulan Manado dan pasar Beriman Tomohon Sampel diambil dari lima penjual yang berbeda dari setiap pasar, untuk pasar Pinasungkulan Manado diberi kode $\mathrm{IM}_{1}, \mathrm{IM}_{2}, \mathrm{IM}_{3}, \mathrm{IM}_{4}$, IM $\mathrm{IM}_{5}$ sedangkan untuk pasar Beriman Tomohon diberi kode $\mathrm{IT}_{1}, \mathrm{IT}_{2}, \mathrm{IT}_{3}, \mathrm{IT}_{4}, \mathrm{IT}_{5}$. Sampel tahu diambil langsung dari lima pabrik berbeda yang ada di kota Manado dan Tomohon, serta tahu di ambil dari lima penjual yang ada pasar Pinasungkulan Manado dan pasar Beriman Tomohon. Sampel tahu yang berasal dari pabrik Manado diberi kode $\mathrm{TaM}_{1}, \mathrm{TaM}_{2}, \mathrm{TaM}_{3}, \mathrm{TaM}_{4}, \mathrm{TaM}_{5}$, dan sampel tahu yang berasal dari pabrik Tomohon diberi kode $\mathrm{TaT}_{1}, \mathrm{TaT}_{2}, \mathrm{TaT}_{3}, \mathrm{TaT}_{4}, \mathrm{TaT}_{5}$ sedangkan untuk sampel dari pasar Pinasungkulan manado diberi kode $\mathrm{TbM}_{1}, \mathrm{TbM}_{2}, \mathrm{TbM}_{3}, \mathrm{TbM}_{4}, \mathrm{TbM}_{5}$ dan sampel tahu dari pasar Beriman Tomohon diberi kode $\mathrm{TbM}_{1}, \mathrm{TbM}_{2}, \mathrm{TbM}_{3}, \mathrm{TbM}_{4}, \mathrm{TbM}_{5}$. Sampel dipreparasi dengan cara dihaluskan lalu diletakkan dalam wadah, untuk dipakai dalam pengujian selanjutnya.

Uji Kualitatif Formalin(Dumeva et al., 2016).

Uji Formalin Menggunakan Preaksi Schiff. Sebanyak 20 gram sampel dihaluskan dimasukan ke dalam labu destilat, tambahkan $50 \mathrm{~mL}$ akuades, diasamkan dengan $1 \mathrm{~mL} \mathrm{H}_{3} \mathrm{PO}_{4} \quad 85 \%$, kemudian didestilasi. Diambil $2 \mathrm{ml}$ hasil destilat, ditambahkan $0,5 \mathrm{ml} \mathrm{H}_{2} \mathrm{SO}_{4}$ pekat, kemudian tambahkan $0,5 \mathrm{ml}$ 
larutan schiff, jika terbentuk warna merah keunguan maka positif mengandung formalin.

\section{Pengujian Menggunakan Tes Kit Formalin}

20 gram sampel dihaluskan, ditambahkan 20 $\mathrm{ml}$ air panas lalu diaduk dan dibiarkan dingin. Ditambahkan 4 tetes reagen A dan 4 tetes reagen B. Dikocok sebentar dan ditunggu 5-10 menit. Diamati perubahan warna yang terbentuk. Jika terbentuk warna ungu berarti bahan yang diuji positif mengandung formalin.

Pengujian Kuantitatif Formalin (Manoppo et al., 2014)

Untuk penentuan kadar formalin diuat baku seri formalin dengan konsentrasi $0 ; 0,05 ; 0,1 ; 0.15$; 0,$20 ; 0,25 ; 0,30 ; 0,35 ; 0,40 ; 0,45 ; 0,50$ ppm dibuat dari larutan baku formalin $20 \mathrm{ppm}$. Masing-masing larutan dipipet 2,9 mL dan ditambahkan 0,1 yang sudah di tentukan.Diambil $2 \mathrm{~mL}$ hasil destilat ditambahkan 0,5 $\mathrm{mL} \mathrm{H}_{2} \mathrm{SO}_{4}$ 96\%, kemudian ditambahkan 0,5 $\mathrm{mL}$ pereaksi Schiff. Di baca pada spektrofotometri UV-Vis dengan panjang gelombang yang telah ditentukan.

\section{Uji Kualitatif Boraks}

Metode Uji Boraks Menggunakan Kertas Tumerik (Triastuti et al., 2011). Diambil 100 gram kunyit diblender dan disaring sehingga menghasilkan cairan kunyit berwarna kuning, celupkan kertas saring kedalam cairan kunyit tersebut dan keringkan. Hasil dari proses ini disebut kertas tumerik. Selanjutnya, buat kertas yang berfungsi sebagai kontrol positif dengan memasukkan satu sendok teh boraks ke dalam gelas yang berisi air $50 \mathrm{~mL}$ dan diaduk larutan boraks diteteskan pada kertas tumerik yang sudah disiapkan. Diamati perubahan warna pada kertas tumerik. Warna yang dihasilkan tersebut akan dipergunakan sebagai kontrol positif. blender 50 gram bahan, diuji dan ditambahkan $20 \mathrm{ml}$ air dan disaring. Diteteskan air larutan dari bahan makanan yang diuji tersebut pada kertas tumerik. Amati perubahan warna apa yang terjadi pada kertas tumerik. Apabila warnanya sama dengan pada kertas tumerik kontrol positif, maka bahan makanan tersebut mengandung boraks.

\section{Hasil dan Pembahasan \\ Uji Kualitatif Formalin Ikan Asin dan Tahu \\ Ikan asin dan tahu yang di jual dipasar Pinasungkulan Manado dan pasar Beriman Tomohon digunakan sebagai sampel dalam penelitian ini, sampel yang diperoleh dari pasar karombasan, pasar Tomohon, pabrik Manado dan pabrik Tomohon. Sampel ikan asin yang diperoleh dari penjual tidak diproduksi sendiri melainkan sampel diambil dari produsen diluar kota Manado dan Tomohon, sedangkan untuk sampel tahu penjual memperolehnya dari pabrik yang ada di Manado dan Tomohon. \\ Hasil uji kualitatif kandungan formalin pada ikan asin dan tahu ditunjukkan dengan adanya perubahan warna menjadi keunguan pada sampel ketika ditetesi dengan tes kit formalin maupun}

dengan pereaksi schiff. Tes kit formalin digunakan untuk mengikat gugus aldehid yang terdapat pada sampel sama halnya dengan Pereaksi Schiff digunakan untuk mengikat formalin agar terlepas dari sampel sehingga Formalin bereaksi dengan pereaksi Schiff menghasilkan mnghasilkan larutan berwarna merah keunguan (Manoppo et al., 2014). Hasil uji kualitatif formalin dari ikan asin baik yang di peroleh dari pasar Pinasungkulan Manado dan pasar Beriman Tomohon, semua sampel ikan asin memberikan hasil yang positif oleh karena itu untuk sampel ikan asin dilanjutkan dengan analisis kuantitatif formalin. Hasil uji kualitatif formalin dari tahu yang peroleh dari pabrik Manado dan pabrik Tomohon serta pasar Pinasungkulan Manado dan pasar Beriman Tomohon, semua sampel tahu menunjukkan hasil negatif oleh sebab itu untuk sampel tahu tidak dilanjutkan untuk analisis kadar formalinnya.

Berdasarkan hasil penelitian yang ditunjukkan terlihat bahwa untuk sampel ikan asin yang diperoleh dari pasar Berimam Tomohon dan pasar Pinasungkulan semua sampel ikan asin mengandung formalin, hal ini ditunjukkan dengan adanya perubahan warna sampel yang dari tidak berwarna menjadi berwarna ungu sedangkan Tahu dari pabarik Tomohon, pabrik Manado, pasar Berimam Tomohon dan pasar Pinasungkulan Manado tidak mengandung formalin karena tidak terjadi perubahan warna pada sampel. Penelitian lain dilakukan oleh (Kusumawati, 2004) yang menyataka bahwa hasil analisis kualitatif positif ditandai dengan warna ungu yang terbentuk setelah sampel ditetesi dengan pereaksi Schiff dengan volume sama banyak.

Formalin (formaldehid) adalah salah satu zat yang dilarang berada dalam bahan makanan. Pengawet ini memiliki unsur aldehida yang bersifat mudah bereaksi dengan protein, karena ketika disiramkan ke makanan formalin akan mengikat unsur protein (protein menjadi mati atau tidak berfungsi) mulai dari bagian permukaan hingga meresap kebagian dalamnya. Kemudian protein yang telah mati tidak akan diserang bakteri pembusuk yang menghasilkan senyawa asam, itulah sebabnya makanan menjadi lebih awet (Mirna, 2016).

\section{Uji Kuantitatif Formalin}

Penentuan Panjang Gelombang Maksimum

Analisis kuantitatif formalin dilakukan sebagai lanjuttan dari uji kualitatif pada sampel yang menunjukkan hasil yang positif Penentuan panjang gelombang maksimum baku formain yang di baca pada panjang gelombang $400-700 \mathrm{~nm}$, di peroleh pada panjang gelombang $544 \mathrm{~nm}$. Hasil penentuan panjang gelomang dapat dilihat pada Gambar 1. 


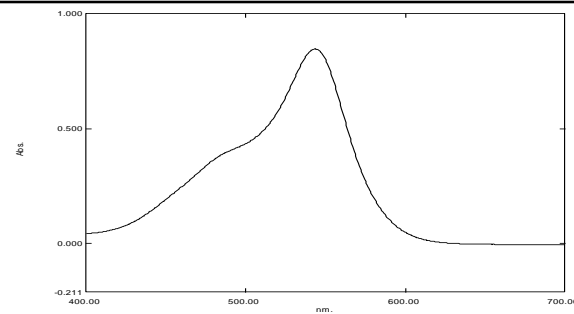

Gambar 1. Panjang Gelombang Maksimum Formalin

Penetapan Kadar Formalin

Penetapan kadar formalin pada sampel hanya dilakukan terhadap sampel yang positif mengandung formalin pada uji kualitatif, sampel ikanasin yang di ujikan dungan formalinya adalah jenis ikan kakatua, sampel ikan asin diambil sebanyak 10 sampel dari 2 pasar yang bebeda. Beradasarkan tabel 2 diketahui bahwa sampel ikan asin yang mengandung formalin, untuk lebih jelasnya dapat dilihat hasil uji kuantitatif dari sampel mengunakan spektrofotometri UV-Vis pada Gambar2.

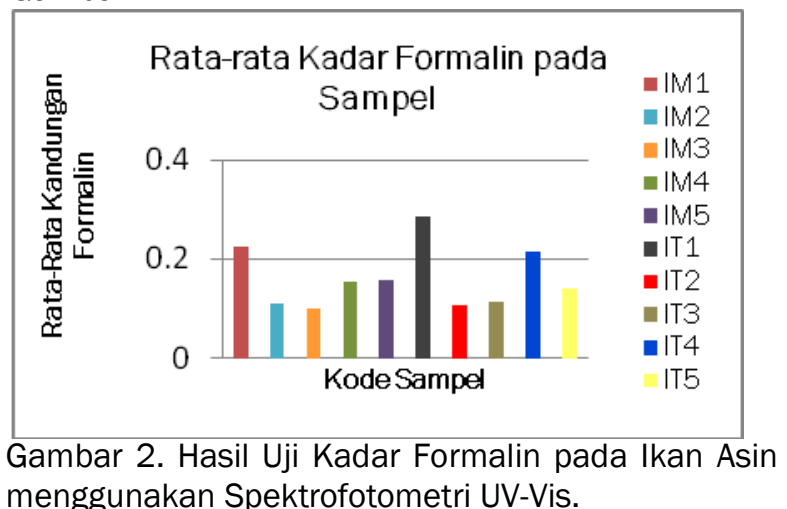

Berdasarkan data yang diperoleh pada Gambar 2 dapat dilihat bahwa formalin yang digunakan sebagai bahan pengawet dalam ikan asin berbedabeda antara ikan asin pasar Manado dan Tomohon, berdasarkan Gambar 2 diatas dapat disimpulkan kadar formalin tertinggi terdapat pada sampel dengan kode IT1 (ikan asin pasar Berimam Tomohon dari penjual yag pertama) dan kadar formalin terendah pada sampel IM3 (ikan asin pasar Pinasungkulan Manado dari penjual ketiga) hal ini menunjukan semakin intensif warna yang tampak, dapat menggambarkan bahwa formalin yang terkandung dalam sampel semakin banyak Perbedaan ini karena sampel yang diperoleh, diambil dari lima penjual yang berbeda-beda pada setiap pasar. Penambahan formalin pada ikan asin karena ikan asin tidak akan terjual seluruhnyadalam satu hari sehingga biasnya pedangang menambahkan formalin sebagai bahan pengawet agar tidak megalami kerugian.

Penggunaan formalin pada ikan asin dilakukan oleh produsen ikan asin. Penggunaan formalin ini bertujuan agar ikan tidak ditumbuhi jamur dan lebih awet. Pemakaian formalin juga dipercaya dapat mempercepat proses pengeringan dan membuat tampilan fisik tidak cepat rusak. Selain itu, penggunaan formalin juga bertujuan untuk meningkatkan rendemen ikan asin. Pembuatan ikan asin dengan garam tanpa penambahan formalin menghasilkan rendemen sekitar $40 \%$, sedangkan ikan asin dengan penambahan formalin rendemennya meningkat menjadi 75\% ( Habibah., 2013).

Ikan asin yang mengandung formalin dapat diketahui lewat ciri-ciri antara lain tidak rusak sampai lebih dari satu bulan pada suhu 250C, bersih, cerah dan tidak berbau khas ikan asin, tidak dihinggapi lalat di area berlalat, Selain itu dagingnya kenyal, utuh, lebih putih dan bersih dibandingkan ikan asin tanpa formalin yang berwarna agak coklat (Widyaningsih dan Murtini, 2006).

Formaldehid dalam makanan dapat menyebabkan keracunan dengan gejala sakit perut akut, muntah-muntah, diare serta depresi susunan saraf. Selain itu, formaldehid juga bersifat korosif, iritatif, dapat menyebabkan perubahan sel dan jaringan tubuh serta bersifat karsinogen. Paparan formaldehid dapat menyebabkan turunnya kadar antioksidan dalam tubuh seperti superoksid dismutase dan glutathione tereduksi GSH), dan meningkatkan produksi senyawa reactive oxygen species (ROS) yang dapat menyebabkan terjadinya stres oksidatif. Stres oksidatif yang berlangsung dapat menyebabkan terjadinya kerusakan lipid, protein bahkan DNA yang pada akhirnya menyebabkan kerusakan pada hepar (Yulisa, 2014).

ACGIH (American Conference of Governmental and Industrial Hygienists) menetapkan ambang batas aman formalin dalam tubuh adalah 0,4 ppm (Alsuhendra dan Ridawati, 2013). Menurut IPCS (International Programme on Chemical Safety), lembaga khusus dari tiga organisasi PBB yaitu ILO, UNEP dan WHO yang peduli pada keselamatan penggunaan bahan-bahan kimia, bahwa secara umum ambang batas aman formalin dalam makanan yang masih bisa ditolerir dalam tubuh orang dewasa adalah 1,5 mg hingga $14 \mathrm{mg}$ per hari sedangkan formalin dalam bentuk air minum yang masih bisa ditolerir dalam tubuh yaitu 0,1 ppm (Singgih, 2013). Kadar formalin terkecil dalam sampel adalah 0,099 ppm, maka berdasarkan batas toleransi formalin yang dapat diterima olehtubuh dalam 1 hari, sampel ikan asin yang diuji tidak aman untuk dikonsumsi.

\section{Uji Kualitatif Boraks}

Hasil pemeriksaan boraks dengan uji warna kertas tumerik dari ikan asin dan tahu, sampel ikan asin dan tahu baik yang diperoleh dari pabrik maupun pasar semua sampel memberikan hasil yang negatif. Kunyit dapat bereaksi dengan asam borat membentuk senyawa berwarna merah, yang dikenal sebagai rosocyanine, sehingga dapat disimpulkan bahwa sampel tahu aman dari boraks, oleh karena itu tidak dilakukan uji kuantitatif boraks. Uji kualitatif boraks dilakukan sistim duplo untuk memastikan keakuratan hasil.

Hasil penelitian yang sama pernah dilakukan oleh (Triastuti., 2013) menyatakan bahwa tahu yang beredar dikota Manado yang di uji menggunakan 
kertas tumerik tidak terdeteksi adanya boraks. Penelitian lain dilakukan oleh Kementrian Riset dan Teknologi di Universitas Negeri Jakarta (2013) melaporkan bahwa paper tes kit atau uji warna kertas tumerik dapat mendeteksi kandungan boraks pada makanan jika kadar minimalnya adalah 200 ppm.

\section{Kesimpulan}

Besar Dari hasilpenelitian ini dapat disimpulkan bahwa pada periode pelaksanaan penelitian ini (April - Mei 2017) tahu yang dijual di Manado dan Tomohon tidak terdeteksi mengandung formalin dan boraks, sedangkan ikan asin yang di jual Manado danTomohonjuga tidak terdeteksi mengandung boraks, tetapi terdeteksi mengandung formalin pada kisaran konsentrasi 0,099-0,289 ppm

\section{Daftar Pustaka}

Alsuhendra., dan Ridawati. 2013. Bahan Toksik dalam Makanan. Rosda, Jakarta.

Bambang, R. 2008. Dasar-Dasar Pembelajaran Perusahan. GPEE, Yogyakarta.

Dumeva, A.P. Pane. R.E., dan Khasianiputri. V. 2016. Uji Kandungan Formalin Pada Buah Pepaya (Carica Pepaya L) Dan Buah Nanas (Ananas comuscus L) yang dijual dilinkungan UIN Raden Fatah Palembang dengan Metode Spektrofotometer. Jurnal Biota. 2(1):76-81.

Habibah, T. P. 2013. Identifikasi Penggunaan Formalin pada Ikan Asin dan Faktor Prilaku Penjual di pasar Tradisional Kota Semarang. Unnes Journal of Public Health. 2(3): 22526528.

Kementrian Riset dan teknologi. 2013. Artikel Paper Tes Kit Sederhana untuk Analisis Kadar Boraks dalam Makanan. Jakarta.

Kusumawati, F dan Trisharyanti D.K. 2004. Penetapan Kadar Formalin yang digunakan sebagai Pengawet dalam Bakmi Basah Di Pasar Wilayah Kota Surakarta. Jurnal Penelitian Sains dan Teknologi. 5(1): 131-140.

Puspasari, G., dan Hadijanto, K. 2014. Uji Kualitatif Formalin dalam Tahu Kuning Di Pasar " $X$ " Kota Bandung. Universitas Kristen Maranatha

Manoppo, G., Abijulu. J., dan Wehantau. F. 2014. Analisis Formalin pada Buah Impor Di Kota Manado. Jurnal IImiah Farmasi UNSRAT. 3(3): 148-155.

Mirna. Karimuna, L., dan Asyik. 2016. Analisis formalin pada ikan asin di beberapa pasar tradisional kota kendari. Journal Sains dan Teknologi Pangan. (1)1: 31-36.

Rinto, E., dan S.B. Arafah. Utama. 2009. Kajian Keamanan Pangan (Formalin, Garam dan Mikrobia) pada Ikan Sepat Asin Produksi Indralaya. Jurnal Pembangunan Manusia. 8(2): 20-25.

Sari, A.S., Aserina, dan Adrial. 2013. Identifikasi Penggunaan Formalin pada Ikan Asin dan Faktor Perilaku Penjual Dipasar Tradisional
Semarang. Jurnal Of Pubic Healt. 3(3): 22526528.

Sinaga, E.J. 2009. Analisis Kandungan Formalin pada Ikan Kembung Rebus di beberapa Pasar Tradisional Kota Medan [skripsi]. Fakultas Kesehatan Masyarakat Universitas Sumetera Utara, Medan.

Suparwiono, A.M., dan Hudaidah. S. 2014. Evaluasi Kandungan Formalin pada Ikan Asin Dilampung. Jurnal IImu Perikanan dan Sumberdaya Perairan.

Triastuti, E. Fatimawali., dan Runtuwene. J.R. 2013. Analisis Boraks pada Tahu yang Diproduksi di Kota Manado. Jurnal IImiah Farmasi UNSRAT. 2(1): 2302-2493.

Widyaningsih, T.D., dan Murtini, E. 2006. Alternatif pengganti formalin pada produk pangan. Trubus Agrisarana. Jakarta. 